
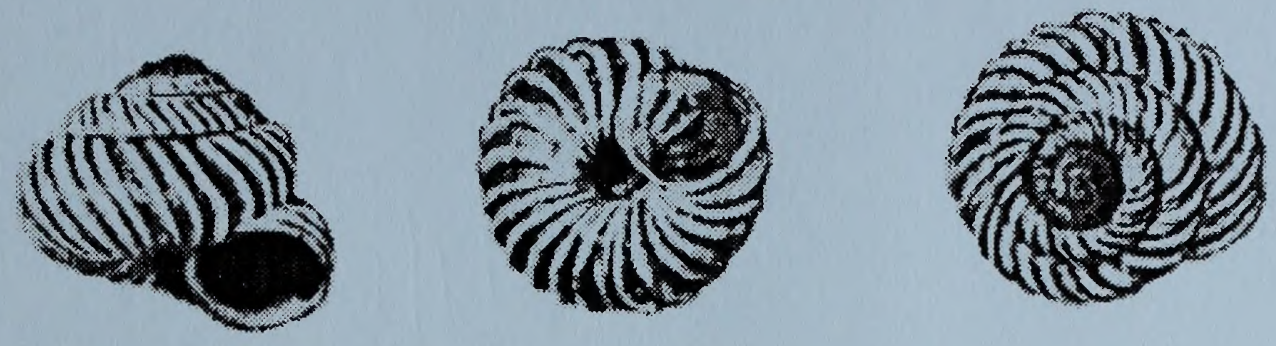

\title{
Land Snails of the Lucile Caves ACEC
}

\author{
by \\ Terrence J. Frest \\ Edward J. Johannes
}

\section{QL}

84.2

. L 352

no.

97-16 



\section{LAND SNAILS OF THE LUCILE CAVES ACEC}

Terrence J. Frest

Edward J. Johannes

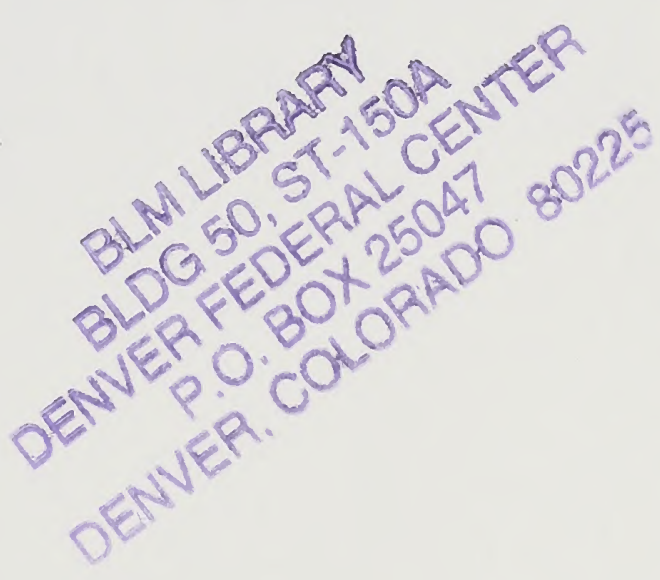

Deixis Consultants 2517 NE 65th Street

Seattle, WA 98115-7125 

Oreohelix idahoensis idahoensis ....is one of our prettiest land shells.

H. A. Pilsbry (1939)

a deliberate conspiracy of silence has kept most subsequent records, and description of a new species, from publication. Unlike most species of Oreohelix, those of the Salmon River Valley are highly restricted in distribution, capable of being wiped out by zealous collectors, and often known from less than four colonies.

G. Alan Solem, in Solem \& Clarke (1974) 



\begin{abstract}
A land snail survey was conducted on the Lucile Caves ACEC and vicinity in 1993-1994, as part of a larger survey of the Lower Salmon River valley land snail fauna (Frest \& Johannes, 1995). Information gathered from earlier collections in 1989-1993 was also included. The area was known to include at least one population, possibly discovered in the 1860s, of the federal C2 candidate species Oreohelix idahoensis idahoensis (Newcomb, 1866). We collected at a total of 16 sites, 12 of which were wholly or mostly on the Lucile Caves ACEC.

There are at least 8 land snail species in this vicinity, including colonies of three taxa regarded as Sensitive by Frest \& Johannes (1995a). One of these, Oreohelix idahoensis idahoensis, was historically generally distributed over much of the Lucile Caves ACEC. H now appears to be much reduced in numbers or exterpated in most places, with large populations limited mostly to small areas in the western and southwestern portions of the ACEC. Cryptomastix n. sp. 5 is found only in a small seepy area below Lucile Cave. Oreohelix n. sp. 20 occurs in nearby Sheep Gulch and may be found in scattered areas at high elevations on or just east of the ACEC.

Ecology of sensitive species on the ACEC is described; and recommendations for their management are made. The greatest single human impact in this area stems from grazing of domestic animals.
\end{abstract}





\section{TABLE OF CONTENTS}

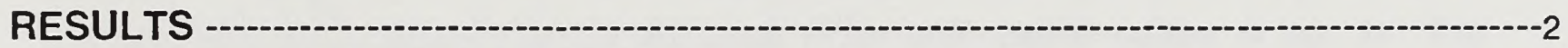

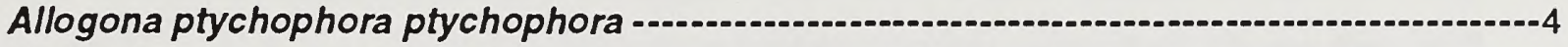

Catinella avara -

Cryptomastix (Cryptomastix) n. sp. 5

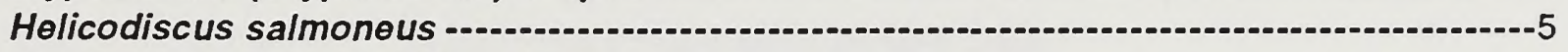

Oreohelix idahoensis idahoensis -

Oreohelix n. sp. 20 -

Pupilla hebes -

Vallonia cyclophorella

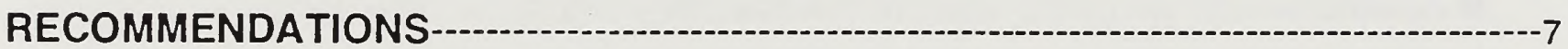

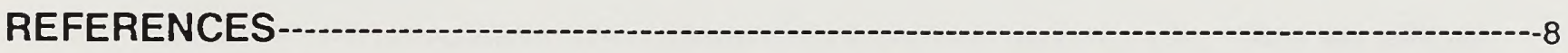

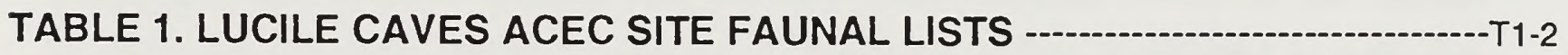

APPENDIX A. LUCILE CAVES ACEC SITES --

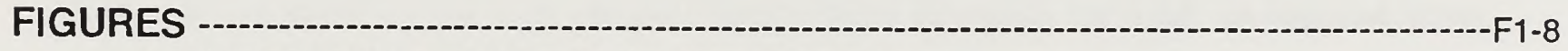

1. MAP OF LUCILE CAVES ACEC AND VICINITY -_-

2. LAND SNAIL SITES IN LUCILE CAVES ACEC AND VICINITY -._-_-_.

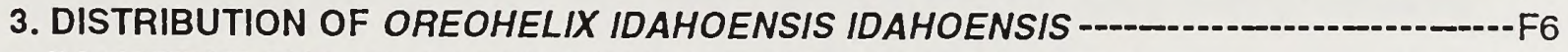

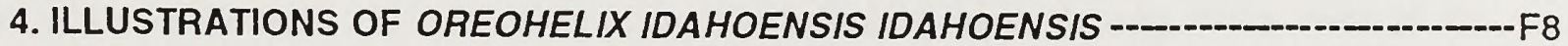





\section{LAND SNAILS OF THE LUCILE CAVES ACEC}

\section{INTRODUCTION}

The Lucile Caves area comprises roughly 440 acres of BLM land just east of the Salmon River and southeast of Lucile, Idaho Co., ID (Figure 1). A main attraction of this land parcel is the limestone cave and associated springs and seeps in the north central portion of sec. 11 . This feature and the surrounding BLM holdings were designated as both a Research Natural Area and Area of Critical Environmental Concern in 1989. Most of the ACEC occurs in portions of sections 2, 11, and 12, T 25 NR 1 E, between Sheep Gulch and Crawford Creek.

The area has long been known to harbor unique floral and faunal elements. Results of floristic and vegetation survey were published in 1991 (Moseley \& Bernatas, 1991). This work reviews the physical environment, flora, and plant communities in some detail; and should be referred to for background. A highlight of Moseley and Bematas (1991) was the confirmation of the survival of a study population of Mirabilis macfarlanei, as well as populations of four additional rare vascular plant species.

As might be predicted from the presence of so many rare plant species, there are unique or unusual animal elements as well. One land snail taxon, currently known as the costate mountainsnail [Oreohelix idahoensis idahoensis (Newcomb, 1866)], is believed to have first been collected from the Lucile area in the early 1860s (Solem, 1975; Frest \& Johannes, 1995a). This taxon, well known to shell collectors and termed "one of our prettiest land shells" by Pilsbry (1939), was first found by the earty private collector Henry Hemphill. Hemphill, an itinerant stone mason, also collected and sold shells. He was particularly active in the period from 1860-1920, and is known to have visited this region in the 19860 s and in the 1890 s. Many other professional malacologists and private collectors have since also collected here. Among these were $H$. B. Baker, H. E. Ashmun, A. G. Smith, M. L. Walton, W. M. Miller, and G. A. Solem (Frest \& Johannes, 1995a).

Specimens from Hemphill's original collection were distributed widely, and are found in major natural history collections throughout the world. The exact site at which he obtained the original lot is somewhat conjectural. Pilsbry (1939) noted that "Hemphill was a good collector but weak at labeling his shells"; this might have been as much to control supply as for other reasons (Coan \& Roth, 1987). The original locality was cited as 'between Idaho City and the Coeur d'Alene 

mining district"; other labels with Hemphill specimens are similarty vague, e.g. "Salmon River Mountains"; fortunately, at least one fixes the site somewhat more precisely as "Lucile" (Pilsbry, 1939). Other old collections, e.g. H. B. Baker, 1930, "below cave about $11 / 2$ miles south of Lucile", are clearly from the Lucile Caves area. It is quite likely that the specimens collected by Hemphill came from the Lucile Caves area, as this is the largest known colony, and along the older main road through the Lower Salmon River valley just as it is today. Hence, it is probable that this is the type locality of Oreohelix idahoensis idahoensis. Some possibility remains, however, that the specimens came from the colony at Lucile (see Solem, 1975; Frest \& Johannes, 1995a).

\section{SCOPE AND METHODS}

Methods used for this survey were a combination of hand and litter sampling, as detailed in Frest \& Johannes $(1995 a, b)$. We visited a total of 16 sites either on the Lucile Caves ACEC or in the immediate vicinity (see Table 1 and Figure 2). Twelve localities were wholly or partly on the ACEC; a few others were added to establish colony boundaries for Oreohelix idahoensis idahoensis. Some other sites collected during the Lower Salmon River survey are also close by: for these, see Frest \& Johannes (1995a). Most sites were hand collected, since there is very little adequate litter on the ACEC. Still, one site (74) was litter sampled.

The area was intensively surveyed between October 15-21, 1993. We had earlier examined some of the same sites on August 10, 1989 and October 1, 1990. Details of site location, flora, and legal descriptions are included in Appendix A; sites are mapped on Figure 2. Faunal lists constitute Table 1.

\section{RESULTS}

We noted a total of eight land snail species at our sites (Table 1). This is rather low for continental areas, but more typical for semiarid regions, and in line with diversities noted elsewhere in the Lower Salmon River area (for local background, see Frest \& Johannes, 1995a; for regional (Interior Columbia Basin) generally, consult Frest \& Johannes (1995b). The litter 

sampled site, as would be expected, had the greatest diversity. Generally, as is regionally characteristic, a single species was locally dominant at each locality; and many sites had just one or two taxa. Most land snails collected were comparatively large, that is over $1 \mathrm{~cm}$ in diameter. This is not necessarily typical of semiarid regions; but quite in line with results from the broader survey.

Diversity in general had little to do with substrate; but abundances may show regolith influence. Much of the central part of the ACEC is underlain by a single large exotic limestone block, most likely Triassic Martin Bridge Limestone. The northern portion of the ACEC, i.e. the acreage in section 2 and the adjoining areas south of Crawford Creek have Lucile Slate bedrock and outcrops. In general, limestone areas in this region, as elsewhere in North America, have more diverse land snail faunas, in part because many snails are calciphiles and all need such elements as calcium for [calcite] shell formation. Limestone, dolomite, or marble are among the best rock units for producing calcium-rich soils. Slates are generally less acceptable. However, the Lucile Slate seems to be unusually calcareous, providing more than sufficient material for shell formation; and shells from both regoliths (for example of the rather thick-shelled Oreohelix idahoensis idahoensis) appear equally robust.

Near the Salmon River proper, boulder piles, of mixed lithologies but including limestone, predominate. Locally, there are extensive sandy areas, notably near the center of section 11 . Both represent Pleistocene and Holocene terrace deposits. Outcrops of both slate and slightly metamorphosed limestone are common, as are small-scale limestone talus piles.

Springs and seeps are mostly confined to a 15 acre area near and below Lucile Cave. Secondary travertine deposition is common in this area. The limestone has local cave and adit development elsewhere in the area. Much of the ACEC has west-facing, moderately dissected slopes. It is mostly comparatively dry and open. Mining prospects and small-scale operations have occurred sporadically, mostly some time ago. This is most evident in the slate outcrop area in section 2; but other prospects and adits occur, such as that at site 208. Limestone/slate contact mining, as occurs commonly elsewhere in this district, is not evident here, with the closest example being the old McKinley Mine in Sheep Gulch.

Former homestead and other buildings have mostly been removed, and traces of impacts from these are most notable within a few hundred feet of the current US 95 right-of-way. The former highway alignment is very evident in the north and central parts of the western border of the ACEC. All of these activities have impacted snails, and most of the areas so impacted still lack live colonies, even though very old dead shells are evident. Former sites for some species, such as that of Smith (1943) for Oreohelix idahoensis idahoensis, appear to have been extipated. However, the most significant impact over most of the ACEC is cattle and horse grazing. Portions of the area have been fenced, notably near the spring and seep area; but fencing is not 

particularly effective over most of the ACEC, and we have observed varying numbers of cattle or horses on each visit.

Short species discussions for each land snail taxon noted during this survey follow; for

further background, including ecology, regional and local occurrence, plant associates, and substrate preferences, see the companion report (Frest \& Johannes, 1995a) or the recent regional synthesis (Frest \& Johannes, 1995b).

\section{Allogona ptychophora ptychophora (Brown, 1870) dry land forestsnail}

This subspecies was the most common taxon encountered during the Lower Salmon River survey (Frest \& Johannes, 1995a) and is common in this area and elsewhere in the Interior Columbia Basin (Frest \& Johannes, 1995b). We classified it as a nonsensitive species in this area. The dry land forestsnail was found in the ACEC and vicinity at the following six sites: $51,52,54$, $75,76,207$. Ecology here was similar to that noted for the region. This large land snail occurs most often in talus and boulder piles, in xeric to somewhat mesic settings. It is most common in the vicinity of Lucile Cave and the wet areas immediately below; but occurs to the slope base.

\section{Catinella avara (Say, 1819) suboval ambersnail}

Snails in the Lower Salmon River area are only tentatively assigned to this species, as discussed by Frest \& Johannes (1995a: there designated a species of uncertain status). Material was inadequate; and ecology (many succineids, including this species elsewhere, prefer moist environments) indicates that this succineid may be an undescribed local endemic. If so, it is probably a strict local endemic and quite rare. This taxon was noted at two sites: 27 and 74 . Notable is the fact that live specimens were found at one site. The local sites are typical; one is a dry and open rocky talus, in this case limestone; the second is a schist slope. Further work needs to be done to establish ecology and identity of this species. Site 27 is very significant, in that it is one of the few sites yet known with live specimens; this site is outside the present ACEC borders.

\section{Cryptomastix (Cryptomastix) n. sp. $5 \quad$ Lucile oregonian}

The Lucile oregonian is a Sensitive species strictly endemic to a portion of the Lower Salmon River valley between Riggins and the mouth of White Bird Creek (Frest \& Johannes, 1995a). It is known from a total of 40 sites. Here, it was collected at four: $52,54,75$, and 207 . Only one site, 75 , which is the partly fenced shaded and seepy area with travertine deposition at the base of the slope below Lucile Cave, had a substantial population. Dead shells in other areas may 

indicate former widespread distribution, as is frequently the case in the less impacted areas in the Lower Salmon River valley.

\section{Helicodiscus salmoneus Binney, $1886 \quad$ Salmon coil}

This small species is a regional endemic particularly characteristic of the Washingtonian molluscan Province. Despite its somewhat restricted distribution, it is locally common in the Lower Salmon River area and was regarded as a nonsensitive species by Frest \& Johannes (1995a). Helicodiscus salmoneus was noted in the ACEC area at only one site (74), and as dead specimens only. It likely occurs locally elsewhere on the ACEC.

\section{Oreohelix idahoensis idahoensis (Newcomb, 1866) costate mountainsnail}

The costate mountainsnail was noted at a total of fifteen sites $(27,51,52,53,54,55,72$, $73,74,75,76,77,202,207,208$. Of these, it seems likely extipated at three; and is possibly so at 208 as well. This species is a C2 federal candidate for listing under the Endangered Species Act and was regarded as a Sensitive species by Frest \& Johannes (1995a, b). We (op. cit.) recommended listing as Threatened if the Lucile Caves ACEC population can be safeguarded; but Endangered otherwise (see discussion below).

It seems likely that all of our sites here were once parts of a single colony, now somewhat reduced and fragmented due to human impacts. We attempted to map out distribution of this taxon in some detail (Figure 3). The costate mountainsnail appears to have been extirpated from perhaps $40 \%$ of the original area occupied (red portions of Figure 3 ). Judging from the number and condition of dead shells, it is possible that much of the range reduction has taken place rather recently, and is due to grazing. Some areas along US 95, especially in the central portions of section 11, may have been extirpated much earlier; and some very recent local extinction seems to have occurred in the areas west of the present highway alignment and east of the river high water mark. Very old local extipation may have occurred due to mining prospects. In one case, there is little sign of recovery while in the second the old adit provides protection to a very local colony.

Over perhaps an additional $40 \%$ of the area (yellow in Figure 3), live snails are very sparse and local. Often, literally millions of dead shells can be found in these areas, in varying condition but with some comparatively fresh. In mostly scattered areas (green in Figure 3), relatively dense live colonies remain, with one large example occurring in the NW 1/4 SE1/4 section 11 (Figure 3). Most of these subpopulations represent survival due to fortuitous protection. Examples are the mine aditcave at site 208 and the isolated talus pile at site 53 . Other colonies survive in areas too 

steep to graze thoroughly, such as the NW side of the small ravine on the lower end of site 54 and the east side of the ravine at the base of site 52. A similar case is the colony at site 207, which persists at the base of a steep limestone cliff just east of the old road alignment. The most natural site occupies portions of localities 55 and 73. This colony occurs in shrubland community with exceptionally large Artemisia and Celtus. Even here, dead shells far outnumber living [three counts were : 1) live: 6/dead: 123; live: 1/dead: 63; and live: 4/dead 78 . Dead snails may outnumber live in relatively unimpacted sites also; but not, in our experience, by such large ratios. These are more characteristic of sites under considerable stress from one or more causes. Live sites are most generally talus or the base of small rock outcrops: occasionally, bases of large Artemisia or Balsamorhiza may perform similar functions for very local colonies.

This subspecies was noted from a few other sites in the immediate vicinity (Frest \& Johannes, 1995a), none of which are as large as this occurrence. It is a strict focal endemic occurring only from the mouth of Race Creek to Lucile, with most sites being on the east side of the Salmon River (Frest \& Johannes, 1995a; see especially Appendix C30). Some of these sites may represent subfossil colonies. This taxon is a strong xerophile and may be a calciphile as well. Ecology and plant associates have recently been discussed in Frest \& Johannes (1995a). Distribution of this species may be controlled locally by a variety of factors. The species seems to be essentially limited to one exotic terrain block and surrounding slate. Even here, it seems to be restricted to lower elevations. Higher on the same block in Sheep Gulch, the species is replaced by Oreohelix n. sp. 20 [see below for further discussion]. This species may occur in the areas east of the ACEC also. A similar phenomenon was noted with Oreohelix haydeni perplexa nearby (Frest \& Johannes, 1995a).

This subspecies is illustrated on Figure 4.

Oreohelix n. sp. 20 Frest \& Johannes, 1995b

Sheep Gulch mountainsnail

The total present range of this Lower Salmon River strict endemic was estimated as about 15 square miles by Frest \& Johannes (1995a). This species occurs at seven of our Lower Salmon River survey sites, including one here (site 202, which is not on ACEC lands). It may also be found just east of the present boundary of the ACEC, at similar elevations to those noted in Sheep Gulch, that is above 2400' and here perhaps higher than 2800'. The known geographic range is extremely limited (Frest \& Johannes, 1995a, Appendix C39); and we recommended Sensitive status and federal listing of it as Endangered. Like Oreohelix idahoensis idahoensis, this species is a strong xerophile whose range has been impacted heavily by grazing. 



\section{Pupilla hebes (Ancey, 1881) crestless column}

A diminutive taxon, this species is typical of parts of the Washingtonian and Rocky Mountain provinces. In the Lower Salmon region as a whole, it is rather uncommon (nine sites) but fairly widely distributed (Frest \& Johannes, 1995a, Appendix C55). In our more complete survey, we treated this taxon as a Watch List species, presently not in need of protection in the Lower Columbia Basin as a whole but possibly a candidate for special consideration in the future; and in any case only possibly needing protection locally. In the ACEC area, it was noted at two sites (27, 74), one outside present ACEC borders.

\section{Vallonia cyclophorella Sterki, 1892 silky vallonia}

The silky vallonia is a very small taxon quite widespread in some of the Western Division mollusk provinces (see Frest \& Johannes, 1995b for discussion of western U.S. mollusk biogeography). We found this species at fourteen sites in the Lower Salmon River survey and did not recommend it as needing either regional or local protection. There is one known ACEC site (74); and the species may occur locally elsewhere on the property. This taxon is more of an environmental generalist than are many Lower Salmon River species, and was treated as a nonsensitive species in the regional report (Frest \& Johannes, 1995a).

\section{RECOMMENDATIONS}

The effects of various management practices on mollusks have been described by us recently (Frest \& Johannes, 1995a, b) and need not be reiterated in detail here. Most pertinent here is additional control on grazing, particularly in portions of the ACEC with shrubland vegetation and large Oreohelix idahoensis idahoensis colonies. It seems that this taxon could be abundant over nearly the whole of the tract with proper protection; but shrublands between 1800 and $2400^{\prime}$ elevations, especially in steeper areas, may perhaps be easiest to protect and maintain. The area with seep and spring drainage, as well as travertine deposition, is especially diverse and has the only currently definitely viable ACEC population of Cryptomastix (Cryptomastix) n. sp. 5. This portion of the ACEC is partly protected by recent and well-placed fencing at present. 

One significant snail site (27), with a reasonable population of Oreohelix idahoensis idahoensis and "Catinella avara" and Pupilla hebes as well, lies just outside ACEC borders. On the other hand, portions of the ACEC, notably the southeastern area, currently have no viable populations of Sensitive species. Perhaps consideration should be given to some local land swapping to make a more secure, coherent, and more readily defensible ACEC border. Particularly worthwhile in this regard (additional to areas already mentioned) would be incorporation of the SW 1/4 NE 1/4 section 11 into the ACEC, conceivably in exchange for an area such as the SE 1/4 SW 1/4 section 12 or NW 1/4 SW1/4 section 12 (see Figure 1).

We believe that Oreohelix idahoensis idahoensis can tolerate light grazing, such as results from elk and deer populations generally. However, sustained heavy grazing by domestic animals is definitely inimical. Sheep grazing near Lucile, for example, seems to have been the primary or only factor for extirpation since 1990 of one of the two historic sites for the C2 federal candidate Oreohelix waltoni; cattle grazing has much reduced this species at the other historic site, the type locality (Frest \& Johannes, 1995a). Some measures should be taken to decrease grazing pressure on at least critical portions of the ACEC; and exclusion of domestic animals entirely from some areas should be considered. Measures that serve to expand or restore the shrubland plant community should also enhance snail populations as well.

\section{REFERENCES}

Coan, E. \& B. Roth 1987. The malacological taxa of Henry Hemphill. The Veliger 29: 322-339.

Frest, T. J. \& E. J. Johannes. 1995a. Land Snail Survey of the Lower Salmon River Drainage, Idaho. Deixis Consultants, Seattle, Washington. vii +360 pp.

1995b. Interior Columbia Basin Mollusk Species of Special

Concern. Report of Interior Columbia Basin Ecosystem Management Project. Deixis Consultants, Seattle, Washington. xi + 362 pp.

Moseley, R. K. \& S. Bernatas. 1991. A Floristic and Vegetation Survey of Lucile Caves Area of Critical Environmental Concern, Coeur d'Alene District, BLM. Bureau of Land Management, Idaho State Office, Technical Bulletin $91-3, v+41$ pp. appendices.

Pilsbry, H. A. 1939. Land Mollusca of North America (North of Mexico), vol. 1 pt. 1. Academy of Natural Sciences of Philadelphia Monograph 3 (1): 1-574.

Smith, A. G. 1943. Mollusks of the Clearwater Mountains, Idaho. Proceedings, California Academy of Sciences, series 4: 23: 537-554.

Solem, A. 1975. Notes on Salmon River oreohelicid land snails, with description of Oreohelix 


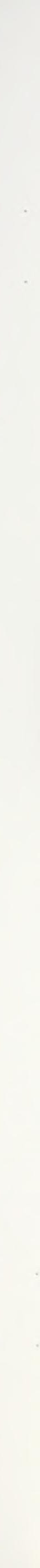


waltoni. Veliger 18: 16-30.

\& A. H. Clarke. 1974. Report on status survey for Salmon River Valley land snails. Office Endangered Species, Washington, DC. 12 pp. [unpub. letter dated August 23, 1974] 


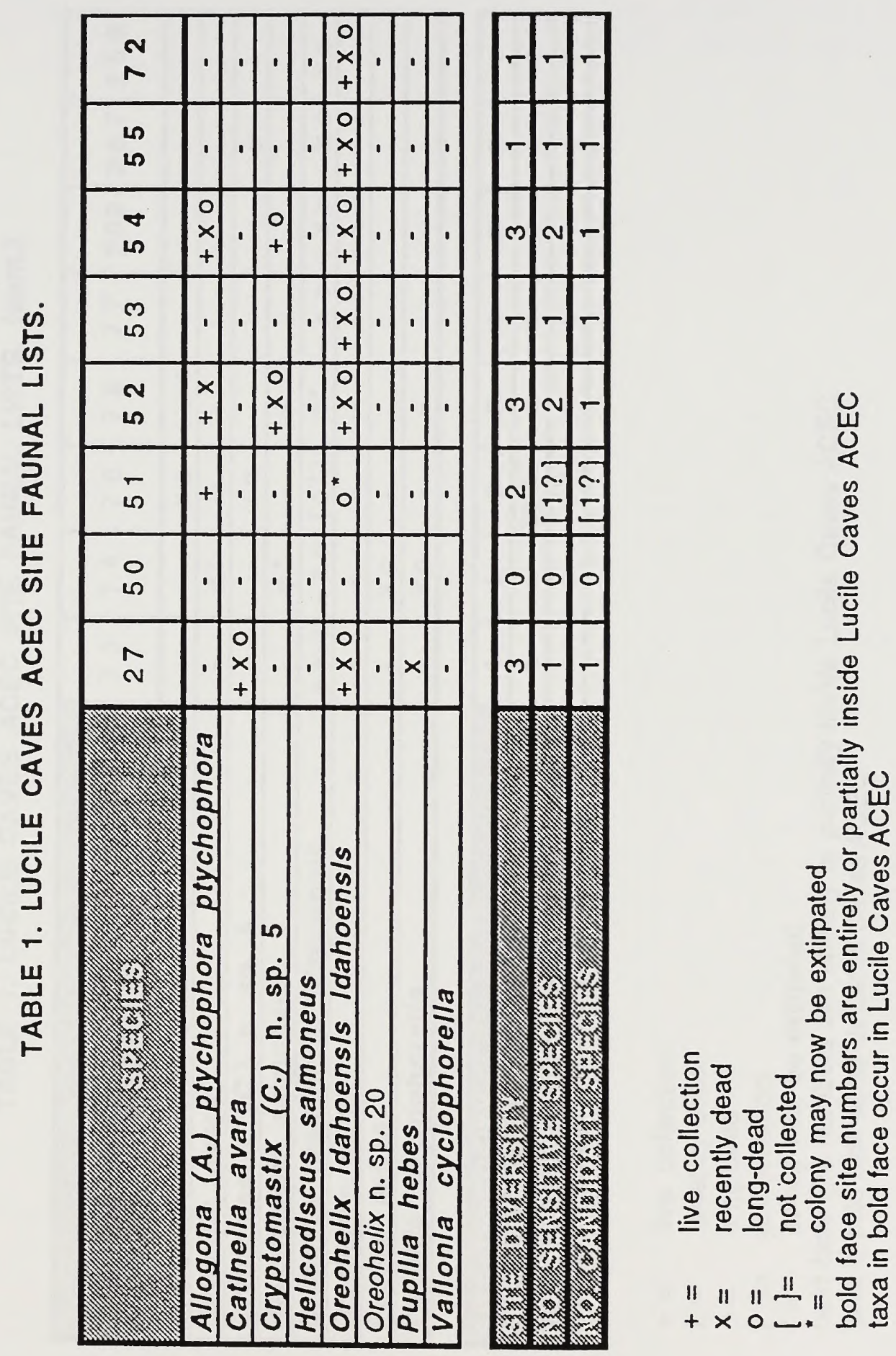

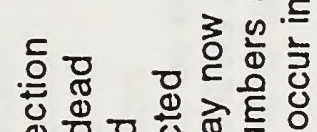

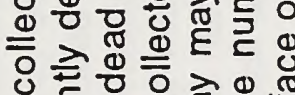

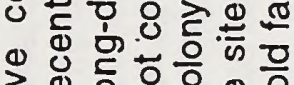

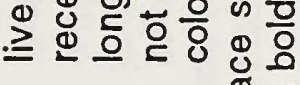

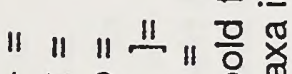
$+\times 0 己$ - 


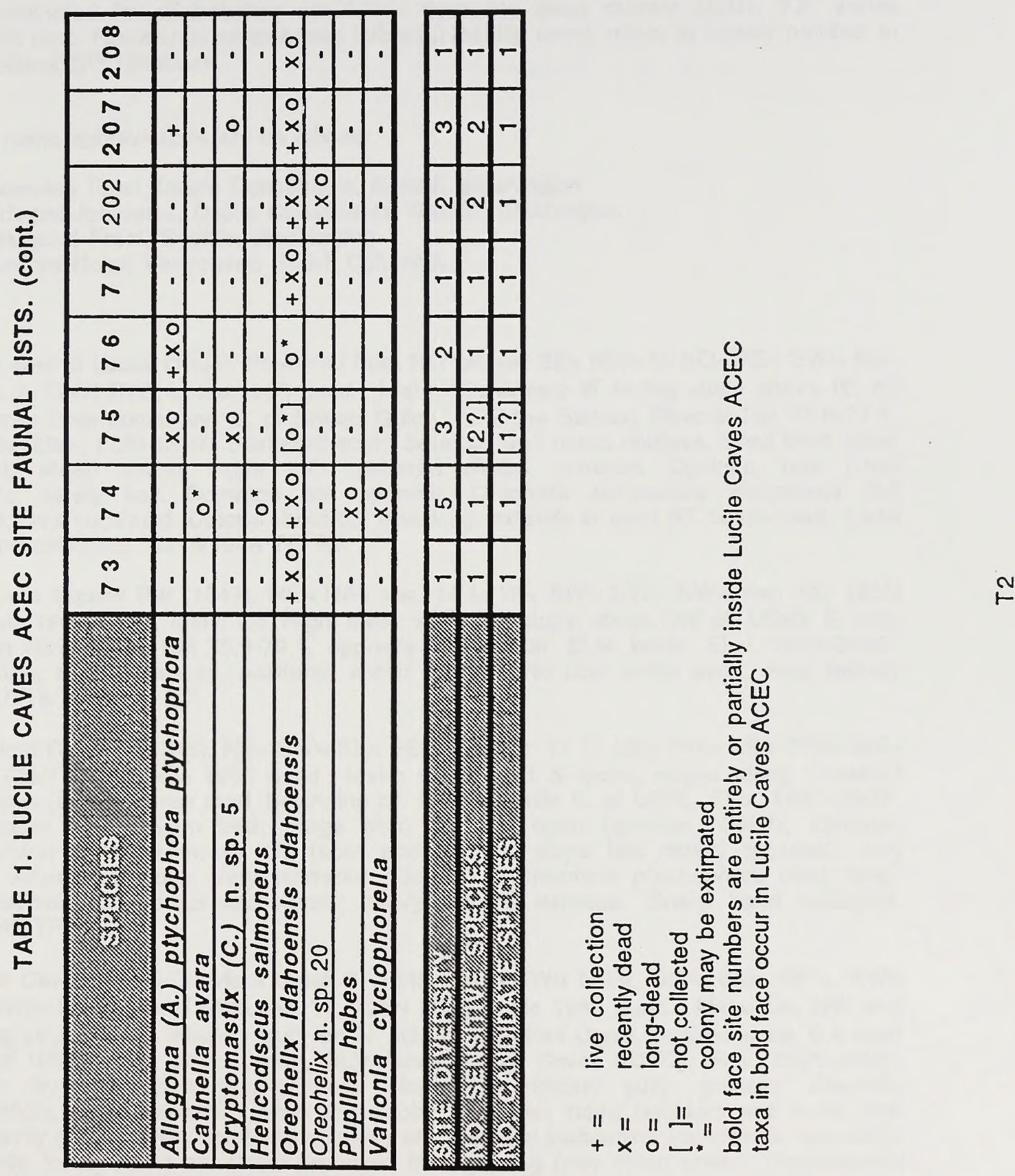

을 잉 응 品 $\frac{\Phi}{0}$ 는 Ф

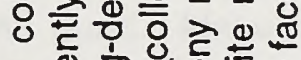

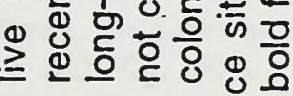
은

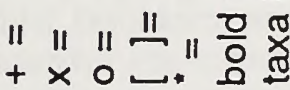





\section{APPENDIX A. LUCILE CAVES ACEC SITES.}

Legal coordinates for all localities are taken from the most current USGS $7.5^{\prime}$ series topographic map. Number in parentheses following locality name refers to locality number in Deixis MolluscDB ${ }^{\text {TM }}$ database.

Collector name abbreviations are as follows:

TF- Terrence Frest, Deixis Consultants, Seattle, Washington

EJ- Edward Johannes, Deixis Consultants, Seattle, Washington

MF- Margaret Frest, Seattle, Washington

GH- George Holm, Vancouver, British Columbia

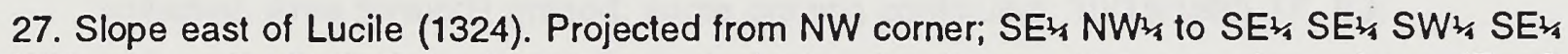
NW' sec. 2, T24N R1E, Lucile 1963 quad., Idaho Co. Grassy W.-facing slope above (E. of) US95 across from Lucile and S. of Sheep Gulch, E. of the Salmon River at RM 77.0-77.1, BLM lands. Elev. 1720-1800'. Scattered schist boulders and mixed cobbles, small talus piles; moderately steep grassy slope with scattered Celtus, common Opuntia, rare Rhus diversiloba; sandy soil. Common but sporadic Oreohelix idahoensis idahoensis (full ontogeny); rare succineid. Colony about 0.2 mile long; extends at least $80^{\prime}$ above road. Land snails hand collected. 10/15/1993 TF, EJ!

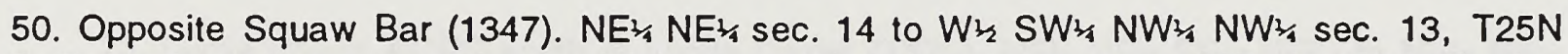
R1E, Lucile 1963 quad., Idaho Co. High, steep W.-facing slope, above (NE of) US95; E. side of Salmon River at ca. RM 78.9-79.1, opposite Squaw Bar, BLM lands. Elev. 1800-2000'. Steep slope; mostly grasses, scattered schist cobbles. No land snails seen, area heavily grazed. 10/18/1993 TF, EJ!

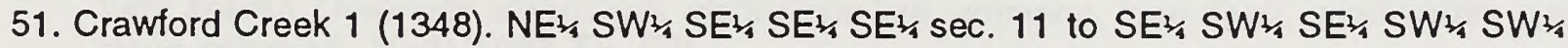
sec. 12, T25N R1E, Lucile 1963 quad., Idaho Co. N. and S.-facing slopes along Crawford Creek above (E. of) access road, beginning ca. 0.3 road mile E. of US95. Elev. 1960-2360'. Steep slopes and stream bed; range from dry and open (grasses, Celtus, Opuntia, Balsamorhiza) to moist mossy cliff faces and shrubby slope (still mostly grasses); very common Rhus diversiloba. Very scattered Allogona ptychophora ptychophora (live); longdead Oreohelix idahoensis idahoensis; heavy grazing damage. Snails hand collected. 10/18/1993 TF, EJ!

52. Lucile Caves ACEC-Crawford Creek 2 (1349). SE1/4 SW NW/4 NW/4, SW SW $1 / 4$, \& NW/1 NE1/4 SW/4 of SW/4 sec. 12, T25N R1E, Lucile 1963 quad., Idaho Co. NW and SW-facing slopes along tributary gully on $\mathrm{N}$. side of Crawford Creek, beginning ca. 0.4 road mile E. of US95 along access road, BLM lands (Lucile Caves ACEC). Elev. 2200-2600'. Relatively dry and open grassy steep slopes in tributary gully; grasses, Opuntia, Balsamorhiza, Celtus, common Rhus diversiloba; scattered schist boulders and small rock piles. Heavily grazed area. Scattered colonies of Oreohelix idahoensis idahoensis, especially on SW side; locally common where protected from grazing (very steep areas); Cryptomastix n. sp. 5. Hand collected. 10/18/1993 TF, EJ!

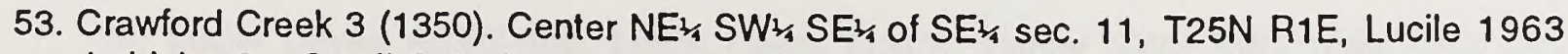
quad., Idaho Co. Small S.-facing talus on N. side of Crawford Creek ca. 0.25 road mile E. of US95, between two major gullies on N. side of Crawford Creek Elev. 2020'. Small (ca. 15' 

length) limestone talus on N.-side of small gully; very open; grasses, Clematis, Celtus. Uncommon Oreohelix idahoensis idahoensis hand collected. 10/18/1993 TF, EJ!

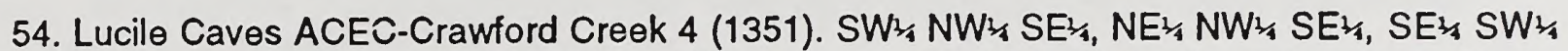
$N^{1 / 4}, S_{1 / 4} S^{1 / 4} N^{1 / 4}, N^{1 / 4} S^{3 / 4} N^{1 / 4}$ of SE/4 sec. 11, T25N R1E, Lucile 1963 quad., Idaho Co. E. and W.-facing slopes in a large gully on N. side of Crawford Creek, beginning ca. 0.25 road mile NE of US95 (E. of Salmon River), partly on BLM lands (Lucile Caves ACEC). Elev. 2000-2400'. Dry open slope along dry gully; schist boulder talus at base; grasses; Opuntia; Celtus; common Rhus diversiloba. Rare live Cryptomastix n. sp. 5, Allogona ptychophora ptychophora; scattered Oreohelix idahoensis idahoensis (some live, but most dead); hand collected. 10/18/1993 TF, EJ!

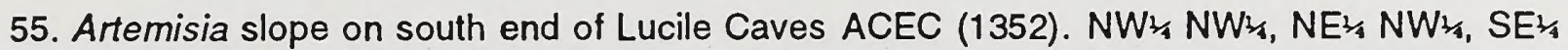
$N W_{1 / 4}, S W_{1 / 4}, N W_{1 / 4}, N W_{1 / 4} S W_{1 / 4}, N E^{1 / 4} S W_{1 / 4}$ of SE⿺𠃊1/4 sec. 11, T25N R1E, Lucile 1963 quad., Idaho Co. Extensive steep SW-facing slope above grassy bench, S. part of BLM Lucile Caves ACEC, E. of US95 and Salmon River; length ca. 0.3 mile; width ca. 0.2 mile. Elev. 2000-2400'. Steep slope with limestone bedrock, scattered talus and boulders; grassy soil with Celtus, common large Artemisia, Opuntia, Balsamorhiza; rather dry and open. Very abundant dead Oreohelix idahoensis idahoensis; relatively common scattered live. Hand collected. Area formerly grazed; some grazing continuing. 10/18/1993 TF, EJ!

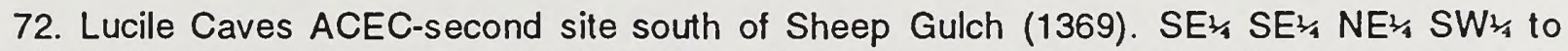
$S^{1 / 4} N_{1 / 4} S_{1 / 4} S^{1 / 4}$ sec. 2, T25N R1E, Lucile 1963 quad., Idaho Co. Shallow-moderately steep W.-facing slope in Lucile Caves ACEC (BLM lands), ca. $0.3 \mathrm{mi}$. S. of Lucile turnoff, above US95 (E. side). Elev. 1800-2600'. Moderately steep-shallow weathered schist slope with scattered limestone cobbles and boulders; mostly dry and open; grasses, scattered Celtus, Artemisa, Balsamorhiza, Opuntia. Very sparse live and dead Oreohelix idahoensis idahoensis hand collected; rather heavily grazed. Live material very local. 10/21/1993 TF, EJ!

73. Lucile Caves ACEC-south of Lucile Caves (1370). NE $E^{\frac{1}{4}} \mathrm{NE}^{1 / 4} \mathrm{SE}^{1 / 4} \mathrm{NW}^{\frac{1}{1 / 4}}$ to $\mathrm{NE}^{1 / 4} \mathrm{NE}^{1 / 4} \mathrm{NE}^{1 / 4}$

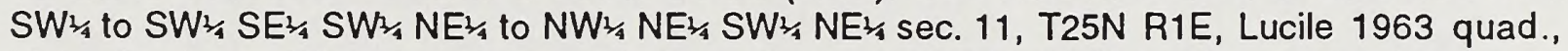
Idaho Co. Large W.-facing slope partly in Lucile Caves ACEC (BLM lands), ca. 0.7-1.1 mi. S. of Lucile turnoff and E. of US95, and S. of Lucile Caves. Elev. 1800-2600'. Steep-moderately steep slope, open, dry, and grassy, in weathered limestone; scattered outcrops and blocks. Very sparse Oreohelix idahoensis idahoensis live; common long-dead; moderately grazed. Hand collected. 10/21/1993 TF, EJ!

74. Lucile Caves ACEC-north site along roadbed (1371). NW/1/4 NE $E^{1 / 4} \mathrm{SE}^{\frac{1}{4}} \mathrm{NE}^{\frac{1}{4}} \mathrm{NW}_{1 / 4}$ sec. 11, T25N R1E, Lucile 1963 quad., Idaho Co. W.-facing schist slope near N. end of old roadbed of US95, ca. 0.6 mi. S. of Lucile turnoff, Lucile Caves ACEC (BLM lands), near old mine prospect. Elev. 1720-1800'. Dry and open slope, with weathered schist outcrops; common grasses, Celtus; locally shaded, with Rubrus, Salix, etc. Oreohelix idahoensis idahoensis hand collected. 8/10/1989 TF, MF, EJ! Local but common Oreohelix idahoensis idahoensis hand collected. Litter sampled. 10/21/1993 TF, EJ!

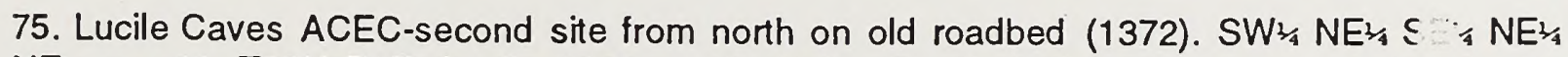
NE $\frac{1 / 4}{4}$ sec. 11, T25N R1E, Lucile 1963 quad., Idaho Co. W.-facing springy area below Lucile Caves and ca. $0.65 \mathrm{mi}$. S. of Lucile turnoff, Lucile Caves ACEC (BLM lands), ca. $0.1 \mathrm{mi}$. S. of N. end of old US95 roadbed. Elev. 1720-1760'. Shaded, moist slope with spring runs, travertine deposition; Salix, Populus, Physocarpus, Cornus stolonifera, Sambucus. Uncommon Cryptomastix n. sp. 5 live; Oreohelix idahoensis idahoensis long-dead (not retained); Allogona ptychophora ptychophora dead only. Hand collected. 8/10/1989 TF, MF, EJ!

76. Lucile Caves ACEC-near Lucile Caves (1373). Center SW/1/4 SW/1/4 NW/4 NE⿺𠃊1/4 sec. 11, T25N R1E, Lucile 1963 quad., Idaho Co. Steep W.-facing travertine-covered area in vicinity of Lucile Caves and below largest spring source, ca. $0.2 \mathrm{mi}$. E. of US95 and $0.7 \mathrm{mi}$. S. of 

Lucile turnoff, BLM lands (Lucile Caves ACEC). Elev. 1960-2020'. Very steep, travertinecovered; open, mostly very moist; grasses, scattered bryophytes, local shrubs. Uncommon Allogona ptychophora ptychophora live; rare long-dead Oreohelix idahoensis idahoensis. Hand collected. 8/10/1989 TF, MF, EJ!

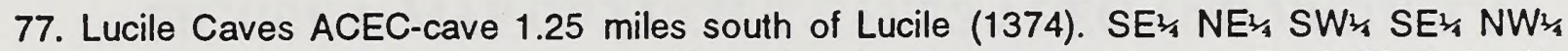
sec. 11, T25N R1E, Lucile 1963 quad., Idaho Co. Small cave opening to E. of US95, Lucile Caves ACEC (BLM lands), ca. $1.25 \mathrm{mi}$. S. of Lucile turnoff. Elev. 1680'. Small cave (former mine prospect?) in short limestone cliff; bare rock, grasses, scattered limestone cobbles and boulders, very limited talus. Oreohelix idahoensis idahoensis extremely local, common where found. Hand collected. 8/10/1989 TF, MF, EJ!

202. Sheep Gulch-lowermost 1.0 mile (2163). Projected from SE corner; N3/2 NE⿺ SW/4 to $\mathrm{NW}_{3 / 4} \mathrm{NE}^{3 / 4} \mathrm{SE}^{1 / 4} \mathrm{NE}^{1 / 4} \mathrm{SE}^{1 / 4}$ sec. 2, T25N R1E, Lucile 1963 quad., Idaho Co. N.facing steep limestone slope on S. side of Sheep Gulch, ca. 0.7-1.0 mi. E. from US95. Elev. 2120-2200'. Steep limestone slope and slope base; mostly open, dry, with grasses; weathered blue schist below; limestone outcrops above. Rare live and dead Oreohelix idahoensis idahoensis in $0.7-$ 0.9 mi. from US95; Oreohelix n. sp. 20 in next 0.1 mi. All hand collected. 10/1/1990 TF, GH!

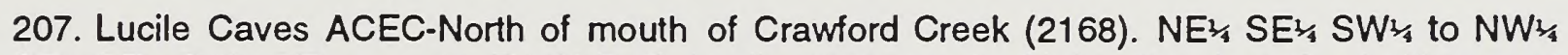
$\mathrm{SE}^{1 / 4} \mathrm{SE}_{1 / 4} \mathrm{SW}_{1 / 4} \mathrm{SE}^{1 / 4} \mathrm{sec}$. 11, T25N R1E, Lucile 1963 quad., Idaho Co. Just E. of US95 and $0.1 \mathrm{mi}$. NW of Crawford Creek, beginning near cliff base and extending $0.2 \mathrm{mi}$. E., Lucile Caves ACEC (BLM lands). Elev. 1680-1800'. Limestone cliff base (W.-facing), partly shaded and wooded, to shallow, rather open and dry limestone outcrop with Sorbus; Artemesia, and grasses. Common but very local Oreohelix idahoensis idahoensis. Hand collected. 10/1/1990 TF, GH!

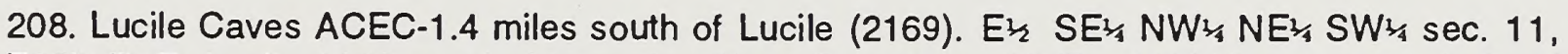
T25N R1E, Lucile 1963 quad., Idaho Co. Short limestone cliff E. of US95 and $1.4 \mathrm{mi}$. S. of Lucile turnoff, Lucile Caves ACEC (BLM lands). Elev. 1720-1760'. Short limestone cliff with minor talus; mostly bedrock, dry, grassy, open; some Sorbus, Rubus, Rhus diversiloba. Common long-dead and recently dead Oreohelix idahoensis idahoensis. 8/10/1989 TF, MF, EJ! 



\section{FIGURE 1. MAP OF LUCILE CAVES ACEC AND VICINITY}

Map of Lucile Caves Area of Critical Environmental Concern [ACEC] and immediate vicinity. Base map derived from Lucille 1963 7.5' USGS topographic map. Each complete section [e.g., section 11] is one mile in width and height. Heavy black line indicates ACEC border. Note location of Salmon River, US 95 on west side of ACEC, and location of Lucile Caves proper [hatched]. Scale for Figures $2 \& 3$ is the same; contour interval is 40'. Most buildings shown on map are no longer extant. 



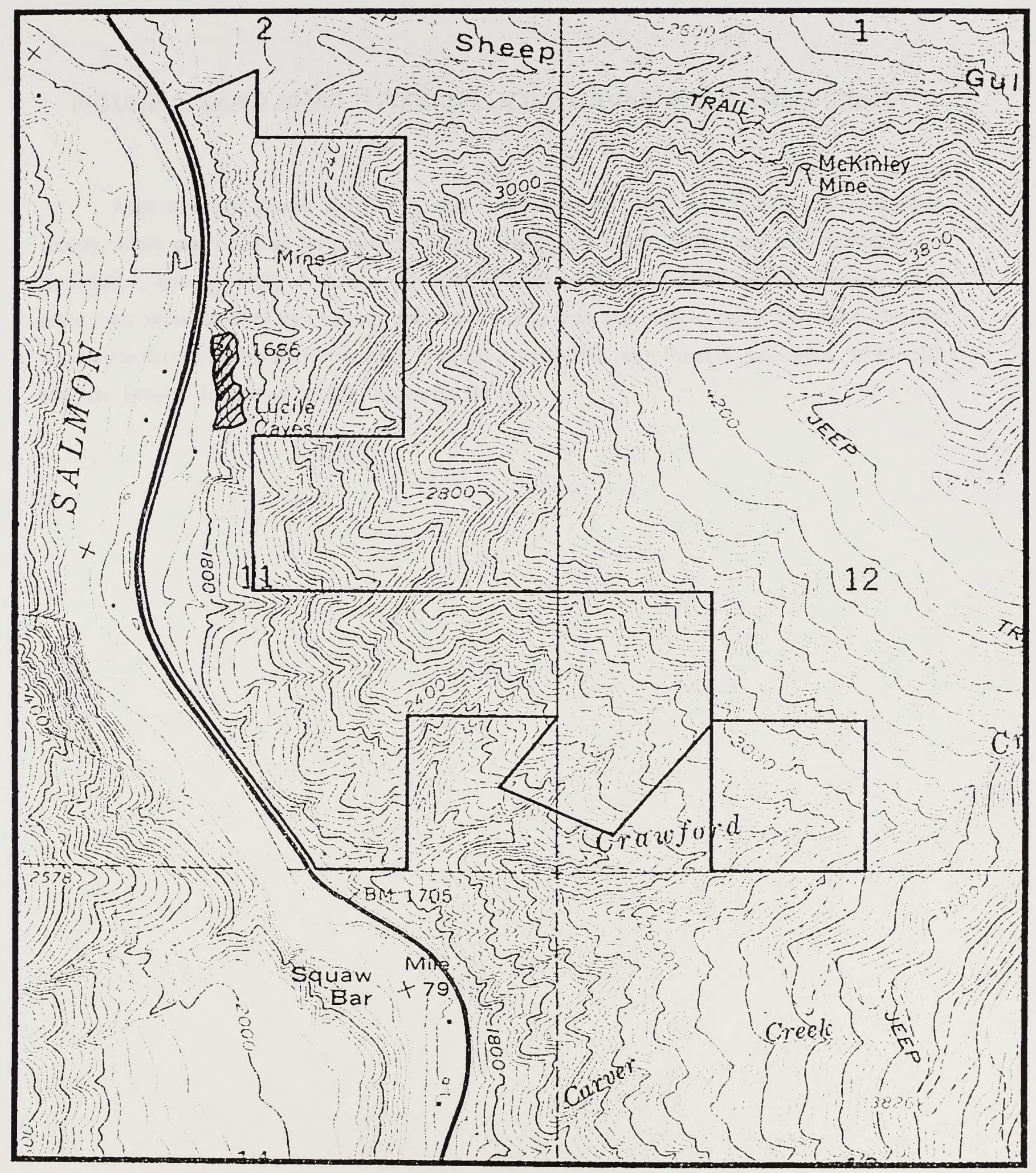

FIGURE 1 



\section{FIGURE 2. LAND SNAIL SITES IN LUCILE CAVES ACEC AND VICINITY}

Map of Lucile Caves Area of Critical Environmental Concern [ACEC] and immediate vicinity; scale and base as for previous figure. Numbered black circles are site numbers; for description, see Appendix A. Areas with black fill were collected in detail and often were visited more than once. Most of intervening and surrounding area was walked once, but not collected; and hence is not numbered herein. For regional perspective, see Frest \& Johannes (1995a, b); see also Frest \& Johannes (1995a, Appendix B17). 



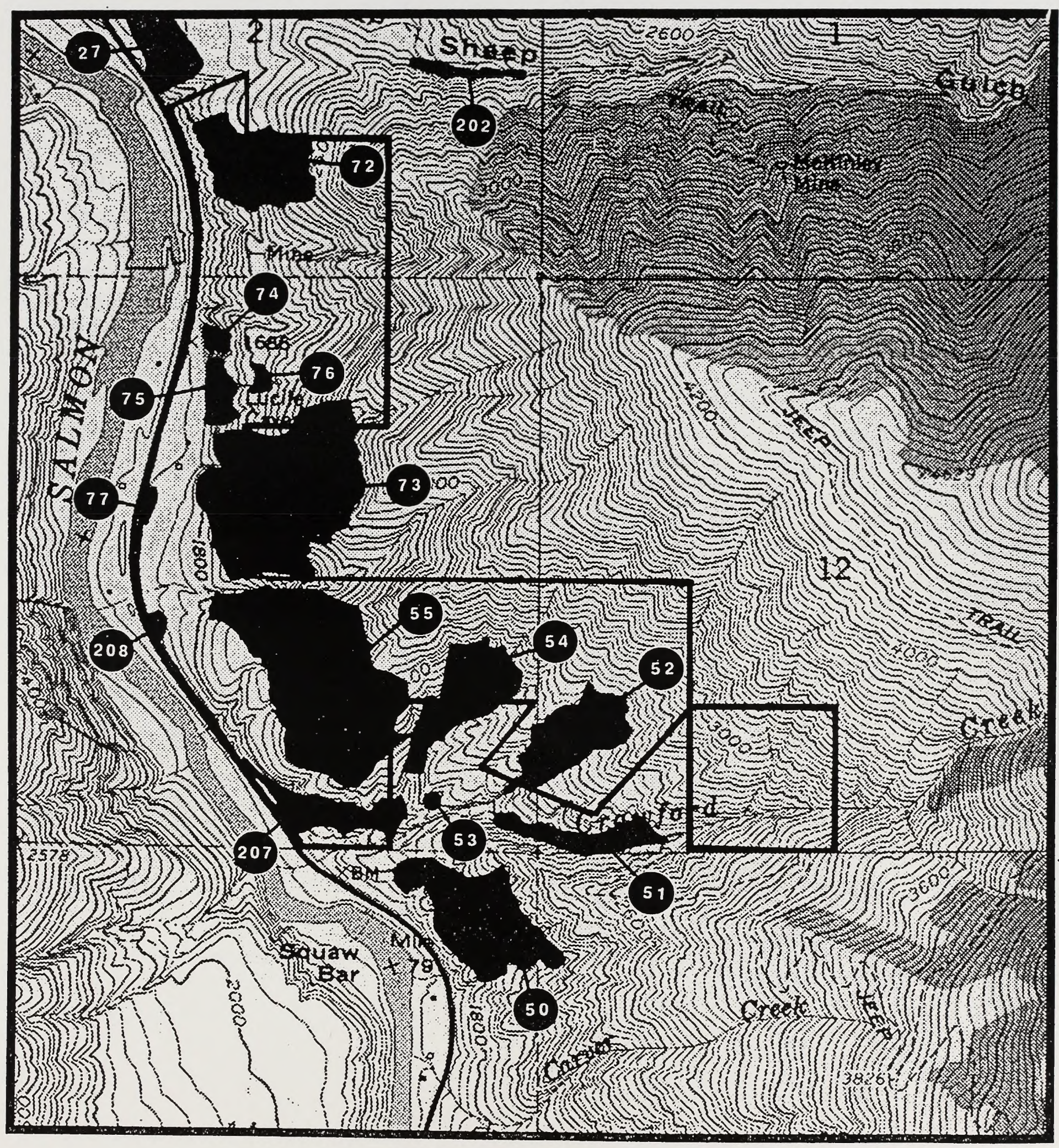

FIGURE 2 



\section{FIGURE 3. DISTRIBUTION OF OREOHELIX IDAHOENSIS IDAHOENSIS (NEWCOMB, 1866) ON LUCILE CAVES ACEC AND IMMEDIATE VICINITY}

Map of Lucile Caves Area of Critical Environmental Concern [ACEC] and immediate vicinity, showing distribution of the $\mathrm{C} 2$ candidate land snails Oreohelix idahoensis idahoensis (Newcomb, 1866). Scale and base as for two previous figures. Area A appears to have dead shells only, but no live specimens; and may mark the former colony boundary. Area B regions have sparse occurrences of live Oreohelix idahoensis idahoensis. Area $\mathrm{C}$ areas commonly had live Oreohelix idahoensis idahoensis in 1994. Note occurrence of area $\mathrm{C}$ surrounded not only by area $\mathrm{B}$, but area $\mathrm{A}$; possibly indicating former large population in intervening or other areas currently with few or no live specimens. For regional perspective, see Frest \& Johannes (1995a). 


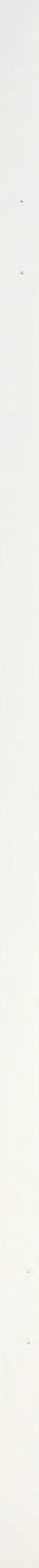




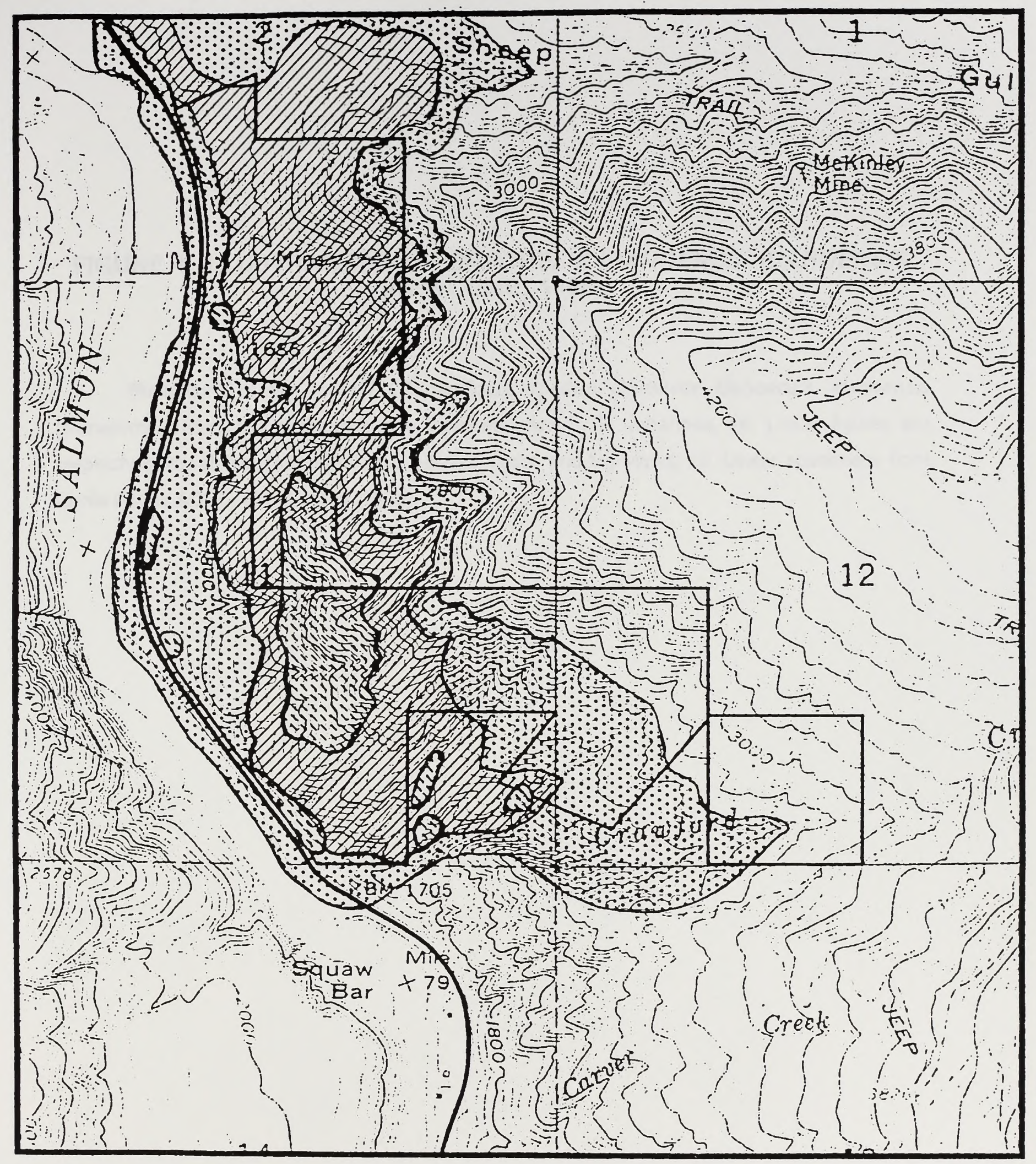

FIGURE 3

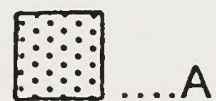

F6

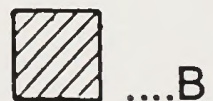

즈는

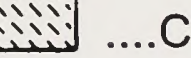





\section{FIGURE 4. ILLUSTRATIONS OF OREOHELIX IDAHOENSIS IDAHOENSIS (NEWCOMB, 1866)}

Illustrations of the federal C2 candidate species Oreohelix idahoensis idahoensis (Nerwcomb, 1866). Upper figure is side (apertural) view by $E$. Johannes, $x 6$. Lower figures are respectively basal, two side (apertural), another basal, and top views, $x 2$. Lower specimens from Lucile Caves ACEC, after Pilsbry (1939). 


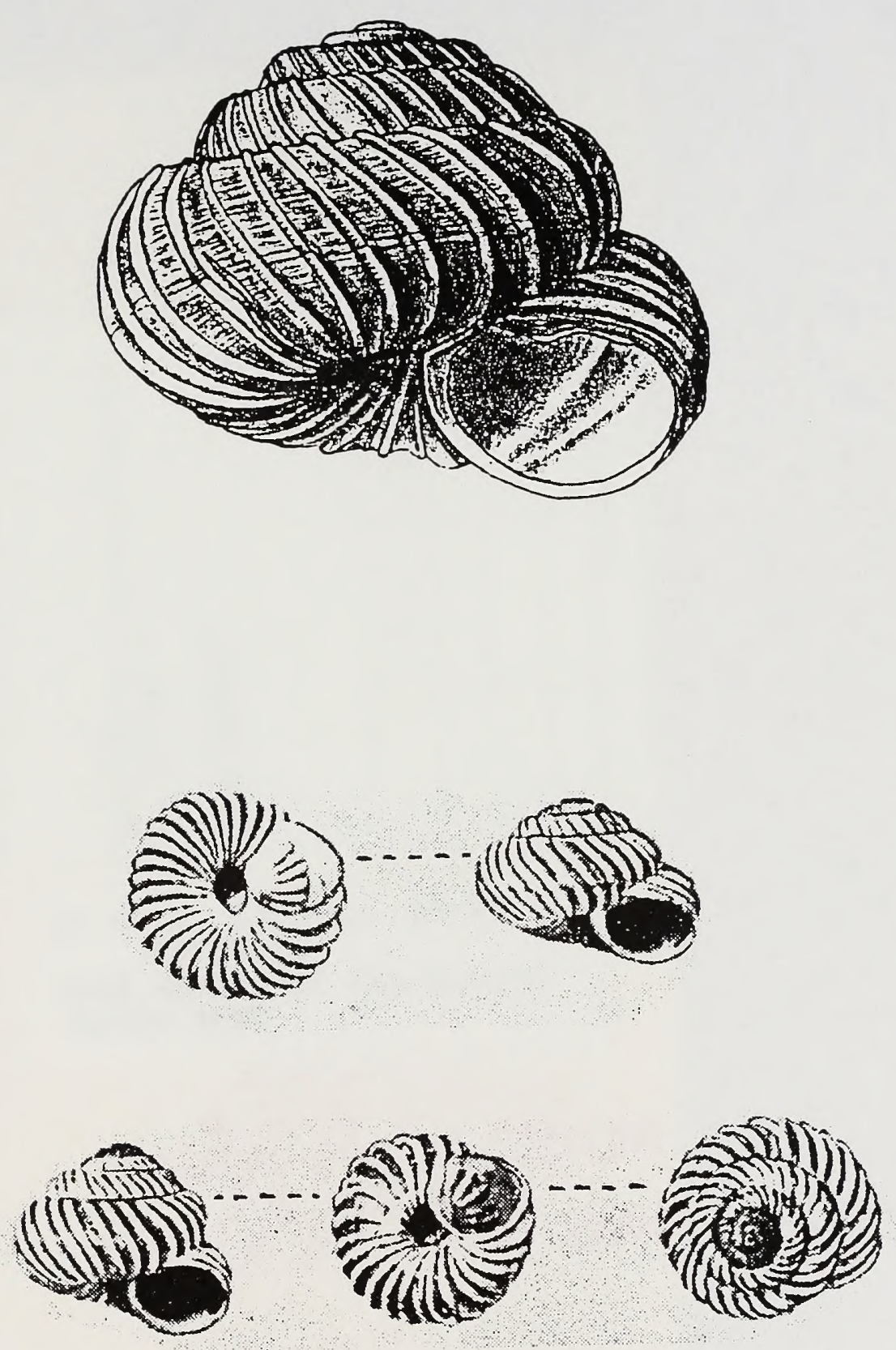

FIGURE 4 



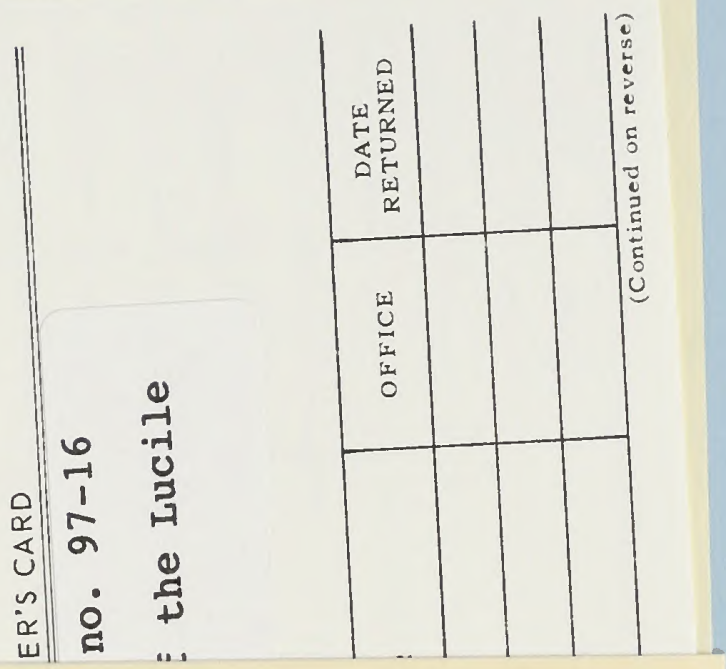

QL 84.2. L352 no. 97-16 88055395

Land snails of the Iucile Caves ACEC

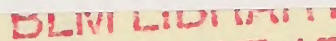
BLDG 50, ST-150A DENVER FEDERAL. CENTER P.O. BOX 25047 DENVER, GOLOFADO 80225 
